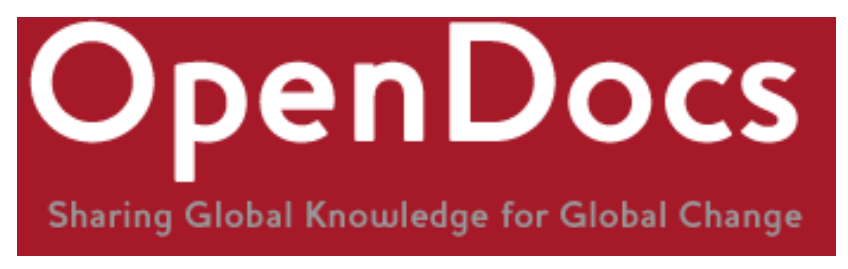

Title: MDG 3 and the negotiation of gender in international education organisations

Citation: North, Amy (2010) MDG 3 and the negotiation of gender in international education organisations. Compare 40 (4), pp. 425-440. DOI: 10.1080/03057925.2010.490363

Official URL: http://dx.doi.org/10.1080/03057925.2010.490363

More details/abstract: Gender equality in education has held a prominent position in global policy making over the last decade through international frameworks and declarations such as the Dakar Framework of Action on Education for All and the Millennium Development Goals (MDGs). This paper draws on interviews conducted with participants who hold a gender brief in international organisations, active in the global Education for All movement. It examines the ways in which global commitments to gender equality in education are being understood in policy and programme work and what this reveals about gender mainstreaming in global education organisations. The MDG framework has been actively used in a number of organisations to leverage action on gender, primarily with regard to improving girls' access to schooling and achieving gender parity - equal numbers of girls and boys in school. This has meant that more substantive understandings of gender, which relate to the experiences of girls and women in and beyond school, often go un-discussed and un-addressed. The need for organisations to develop a more substantive notion of gender equality work linked to activism on women's rights is highlighted as a considerable challenge. This would take gender mainstreaming from a technical exercise to a political contestation with regard to processes of inclusion and exclusion.

Version: Accepted version

Terms of use: This is an Accepted Manuscript of an article published by Taylor \& Francis in Compare on $22^{\text {nd }}$ June 2010. available online at: http://dx.doi.org/10.1080/03057925.2010.490363

This is a download from OpenDocs at the Institute of Development Studies

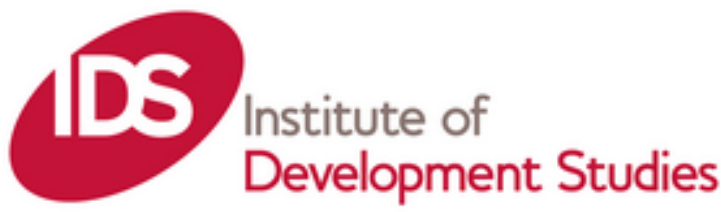




\title{
MDG 3 and the negotiation of gender in international education organisations
}

Amy North

a.north@ioe.ac.uk

\begin{abstract}
Gender equality in education has held a prominent position in global policy making over the last decade through international frameworks and declarations such as the Dakar Framework of Action on Education for All and the Millennium Development Goals (MDGs). This paper draws on interviews conducted with participants who hold a gender brief in international organisations, active in the global Education for All movement. It examines the ways in which global commitments to gender equality in education are being understood in policy and programme work and what this reveals about gender mainstreaming in global education organisations. The MDG framework has been actively used in a number of organisations to leverage action on gender, primarily with regard to improving girls' access to schooling and achieving gender parity-equal numbers of girls and boys in school. This has meant that more substantive understandings of gender, which relate to the experiences of girls and women in and beyond school, often go un-discussed and un-addressed. The need for organisations to develop a more substantive notion of gender equality work linked to activism on women's rights is highlighted as a considerable challenge. This would take gender mainstreaming from a technical exercise to a political contestation with regard to processes of inclusion and exclusion.
\end{abstract}

\section{Introduction}

Gender issues in education have occupied a prominent position in global policy making over the last two decades, with commitments relating to gender and education contained within the Beijing Platform for Action, agreed at the Fourth World Conference on Women in September 1995 and the Dakar framework for Action on Education for All (EFA), and the Millennium Development Goals (MDGs), both ratified in the year 2000. This paper examines the way in which these global gender and education commitments are viewed within international organisations tasked with delivering EFA. It draws on data collected as part of the Gender, Education and Global Poverty Reduction Initiatives project to examine how particular understandings of gender and education contained within the frameworks - and in particular the Millennium Development Goal target of gender parity in education - have been viewed, drawn upon and used within international organisations based in the global north to advance a concern with gender in their education policy, programme and campaigning work. This discussion is used to explore how the privileging of particular narrow interpretations of gender associated with the MDG framework, is linked to the adoption of a limited form of "mainstreaming", while more extended ideas about the politics of the concept and processes of inclusion and exclusion are overlooked.

\section{Gender on the global agenda: The World Conferences on Women}

In the last quarter of the 20th Century important steps were taken to put concerns with women and gender at the heart of international policy, particularly as it related to international development. In 1975, the first World Conference on Women took place in Mexico city, followed by the UN decade for Women (1976-1985). A second World Conference on Women was held in Copenhagen mid way through (1980) and five years later, a third World Conference in Nairobi (1985) was convened to review the achievements of the Decade for Women and develop ten-year action plan for the advancement of women. This series of World conferences culminated in the Fourth World Conference on Women held in Beijing in 1995, at which the Beijing Declaration and Platform for Action was established as "an agenda for women's empowerment"

\footnotetext{
${ }^{1}$ http://www.un.org/womenwatch/daw/beijing/platform/plat1.htm\#statement
} 
states. These events formed the backdrop to a global mobilisation of women's organisations and feminist activists, whose active engagement in and organisation around the conferences was critical to the emergence of a global women's movement (Tinker, 2004). The Beijing Conference in 1995, was attended by 50,000 , representing activists and NGOs as well as the 180 governments who participated in the drafting of the Platform for Action (Unterhalter, 2008).

One of the key outcomes from Beijing, was the establishment of gender mainstreaming as a global strategy for advancing women's empowerment. This was rapidly taken up by governments and international agencies. In 1996 the General Assembly of the United Nations passed a resolution adopting gender mainstreaming as official policy (True, 2003) and in the following years gender mainstreaming policies have been widely adopted in international organisations. Such policies sought to ensure that gender was adopted as a core concern of organisations or departments, and integrated into all areas of their work. However, as Unterhalter and North discuss in the introductory article to this special issue, definitions of gender mainstreaming have taken a number of different forms: while gender mainstreaming policies have often conformed closely to the definition of gender mainstreaming set out by the UN Economic and Social Council in $1997^{2}$, stressing the integration of gender into planning cycles, others have emphasised the importance of concerns with process and changing attitudes and institutional culture.

What gender mainstreaming has meant in practice has alsovaried. Since Beijing, and associated with processes of gender mainstreaming, there have been some important advances regarding attention to gender in the programmes of international organisations: True (2003), for example, points to the launch of flagship programmes on girls' education and women's development, and the inclusion of gender in institutional reform processes at the World Bank under the then president James Wolfensohn. However, a number of feminist commentators have expressed disappointment that the transformative potential of gender mainstreaming has not always been realised. Moser and Moser (2005) for example note that, post Beijing, while most international development institutions have adopted the terminology of gender and the majority have a gender policy, such policy commitments frequently evaporate in planning and implementation processes. A number of factors have been identified as contributing to this, including inadequate resourcing within organisations (True, 2003), lack of accountability mechanisms, and weaknesses at the implementations level (Moser \& Moser, 2005; Walby, 2005). Crucially, critical assessments of mainstreaming experiences have pointed to the way in which mainstreaming has often been viewed as a technical exercise, which fails to recognise the inherently political nature of the advancement of gender equality and women's empowerment (Subrahmanian, 2007; Moser \& Moser, 2005; Mukhopadhyay, 2007; Woodford-Berger, 2007), or take account of the deep contradictions between feminist goals of gender equality and the pursuance of market-driven economic models of development (True, 2003; Rao and Kelleher, 2005; Subrahmanian, 2007). $\quad$ Such critiques highlight the need to pay attention to the political processes of negotiation and contestation that accompany efforts to mainstream gender within organisations (Mukhopadhyay, 2007; WoodfordBerger, 2007). This includes a concern with how gender, equality and empowerment are understood within institutions, and how these different meanings are negotiated (Woodford-Berger, 2007).

\section{EFA and MDGs: Empowerment, Equality and Parity}

Education was established at Beijing as the Platform for Action's second strategic objective, and was identified as a sector in which mainstreaming should occur. However, despite the wealth of

\footnotetext{
${ }^{2}$ United Nations. Report of the Economic and Social Council A/52/3,18 September 1997. http://www.un.org/documents/ecosoc/ docs/1997/e1997-66.htm

${ }^{3}$ Six specific sub-objectives focused on ensuring equal access to education, the eradication of illiteracy and improving women's access to vocational education, science and technology, non-discriminatory education and training, resources for monitoring, and the promotion of lifelong learning
} 
analyses of gender mainstreaming in international organisations as a whole (see Moser \& Moser, 2005; Rao \& Kelleher, 2003, 2005; True, 2003; Rai, 2003), there have been few analyses that have looked specifically at the way in which gender mainstreaming has played out within the education programmes of such organisations. Subrahmanian (2007), noting the progress that has been made in education in increasing the visibility of gender issues in education has, in fact questioned the extent to which such attention to gender can be seen as the result of gender mainstreaming, instead linking this to the Millennium Development Goal target to eliminate gender disparity in primary and secondary school, and the activity that surrounded the run up to the early date set for meeting this target in 2005 .

Certainly, both the Millennium Development Goals (MDGs), which were agreed at the Millennium Summit held in New York in September 2005, and the Dakar framework for Action on Education for All (EFA), which was ratified in April of the same year, have played a critical role in reaffirming the importance of addressing gender issues in education established at Beijing. Each contains a specific goal relating to gender and education. However, how these commitments on gender and education are expressed, the vocabulary they use, and the meanings or understandings of gender that are entailed, varies in subtle, but significant ways between these each of these three international frameworks.

While at Beijing in 1995 the primary emphasis was on women's empowerment, the gender goal (goal five) agreed in the 2000 Dakar Platform for Action seeks to "eliminate gender disparities in primary and secondary education by 2005 , and achieving gender equality in education at all levels by 2015, with a focus on ensuring girls' full and equal access to and achievement in basic education of good quality." It therefore makes no reference to empowerment, and instead emphasises the achievement of "gender equality" in education. An additional Dakar goal - goal four - stresses the importance of women's literacy. The MDG framework of 2000, which contains one goal specifically concerned with women and gender, appears to draw on both Beijing and the Dakar goal five, bringing together the language of empowerment with that of gender equality: MDG 3 seeks to "promote gender equality and empower women". However, significantly, the specific target attached to the goal refers to neither equality nor empowerment, and seeks instead the achievement of gender parity in primary and secondary school by 2005, and at all levels of education by 2015 .

These differences go beyond mere semantics. Framing policy in terms of empowerment, equality, or parity has important implications for the way in which gender issues in education are understood. Thus gender parity, as associated with the MDG3 target, is used to refer to the achievement of equal numbers of girls and boys in school. This conceptualisation of gender places emphasis on the importance of getting girls into school, but does not consider gendered power relations in school, or the gendered experiences and opportunities that boys and girls, and men and women have beyond school. Unterhalter (2007) has referred to such a narrow conceptualisation of gender - limited to a concern with numbers - as gender as a noun, which she contrasts to concerns with gender as an adjective, linked to gendered power relations and their intersection with race and class, and gender as a verb linked to gendered identities. Gender equality and women's empowerment both suggest a conceptualisation of gender that goes beyond numbers (drawing on notions of gender as understood as both an adjective and a verb). Gender equality entails the removal of structures and processes of power, exclusion and discrimination to ensure only equality of access to education, but also of educational experiences and outcomes (Aikman and Unterhalter 2005).Thus, a focus on gender equality in education suggests a need to not only consider numbers of boys and girls within school, but also to look at their experiences of school, and ensure that girls and boys both have opportunities to learn in a safe and supportive environment, in which unequal gender power relations can been challenged (Aikman and Unterhalter, 2005; Fennell and Arnot 2008; Subrahmanian, 2007; Skelton, Francis and Smulyan, 2007). While definitions of women's empowerment are heavily contested, with feminist understandings of empowerment which stress women's agency and the importance of solidarity and collective action (Kabeer, 1999, 2008; Eyben and Napier-Moore 2008), set against a version of women's empowerment seen as a set of technical attributes such as voting or formal wage employment ( Unterhalter and North, 2009, World Bank, 2001), both interpretations point to the importance of looking beyond the school space itself to consider how girls and women are 
able to use their education, and highlight the need to consider the interconnections between schooling and the gendered social, political and economic context within which it is located.

In reducing the complex and multi-faceted notions of gender equality and women's empowerment, contained within the Beijing and Dakar declarations, to a concern with gender parity in schools, the MDG 3 target positions gender equality as something that can be measured and counted. This has important implications for the way in which gender issues are addressed. Whilst, broader concerns with gender equality and women's empowerment suggest a need to look at the content of education, and, for example, address issues such as the way in which gender inequalities may be reproduced or transformed through curriculum or pedagogy, as well as looking beyond the school to tackle, for example women's unequal opportunities in the labour market, the focus on parity suggests that the primary action that should be taken is to get girls in school. Thus policy is focused on specific interventions aimed at increasing access - for example the elimination of school fees, or the provision of stipends for girls (Unterhalter 2007). Although this very narrow conceptualisation of gender has been heavily critiqued (North, 2006; Unterhalter, 2005, 2007; Kabeer 2008, Barton, 2005), it has occupied a prominent place in global thinking, monitoring and reporting on gender and education since 2000, as evidenced, for example by the focus on gender parity in the Education For All Global Monitoring reports (UNESCO 2005, 2006, 2007, 2008).

The following sections draw on data collected in 2007-2010 to explore the ways in which international organisations have taken up, used, or contested the MDG target in their efforts to advance a concern with gender within their own and partner organisations, and the implications this has had for understanding processes of mainstreaming gender within their work.

\section{About the research}

The data on which this paper is based was collected as a component of the Gender, Education and Global Poverty Reduction Initiatives project. The project as a whole is examining the way in which initiatives which engage with global aspirations to advance gender equality in and through schooling in contexts of poverty are understood, interpreted and acted on in different sites, with a particular focus on Kenya and South Africa, as well as global organisations. This paper does not report on data collected in Kenya and South Africa, but examines data collected through interviews conducted with key informants in global organisations engaged with EFA in the UK and the USA. This global component of the research seeks to contribute to the project's understanding of the connections and disjunctures between global, national, regional and local policy and practice regarding gender, education and poverty reduction by revealing the ways in which international agencies interpret and work on issues regarding gender, education and poverty and how they interact with, influence, and are influenced by others at local, national and global levels ${ }^{4}$.

The paper analyses data collected through a series of ten in-depth semi-structured interviews conducted with key figures within agencies actively engaged in the global Education For All movement. Participants were drawn from a number of different types of international organisations. Six participants came from global civil society organisations: either international NGOs or international coalitions of civil society groups. Two participants were from a bi-lateral donor agency. Two participants were from a UN agency and UN-based partnership. All research participants were based in and work from countries in the global North, although the official "location" of their organisations varied: Most participants were from organisations that had their headquarters and

\footnotetext{
4 Moreover, as a collaborative research team split between Kenya, South Africa and UK we felt that it was important to ensure that our own research focus and methodologies did not themselves contribute to reproducing vertical neo-colonial power relations, by making Kenya and South Africa subjects of our research without also scrutinizing institutions in the North and in the UK. This global research turns the gaze onto Northern based policy makers in global institutions, as they too become the subject of our scrutiny.
} 
official base in the global North although a smaller number were based within organisations or networks that had either moved to Southern based headquarters, or which represented a coalition of organisations from both the North and the South. All the participants interviewed work in complex organisations which operate at multiple levels: from global policy work, campaigning and mobilisation in the North and across continents, partnerships with - or influencing of - national governments, and work with local offices and partnerships on the ground.

Participants were selected because they represented key figures working on issues relating to gender equality in education within their organization, and, in most cases, were, in addition, active in global policy formulation and action. This took a number of forms, notably through participation in networks or coalitions or membership of key committees concerned with the disbursement of funds. Half the participants had a remit specifically focused on education, either as education team leads or senior advisors, and the remainder had roles which specifically sought to bring together concerns with education and gender. Of the ten participants, nine were female and one was male.

All the interviews except one - which was conducted over the phone - were carried out faceto-face. Interviews invited participants to reflect on the meaning of gender equality in education, the nature of the challenges in achieving this globally and in particular contexts, and the value of global frameworks, including the Dakar EFA and the MDG frameworks in encouraging action within their organisation or with partners. Interviews also explored the ways in which gender was considered in participants' work and within their organisations generally, not only the sections that dealt with gender or education. The interviews themselves provided a space for reflection and critique, enabling participants to discuss and question their own understandings of the concepts of gender and education and the implications of particular individual and institutional approaches to gender for their policy and practice. A number of participants explicitly welcomed the opportunities this provided. One interviewee explained,

"...what you have done - I have also been reflecting on these issues too. I was like, "I don't know how I am going to answer these questions" but [the interview] has really helped me reflect"

Participants who agreed to be interviewed did so under the guarantee of anonymity: information sheets shared with participants explained that neither they nor their organisations would be mentioned by name in articles or other documents arising from the research. This guarantee was important to enable participants to speak openly about the challenges of working on gender and education within and beyond their own organisations, and to share personal reflections that sometimes varied from, or even contradicted their organisation's official institutional position. This paper therefore does not refer to participants by name when discussing the interview data or name the organisations from which participants were drawn. While this limits the extent to which it is possible to conduct detailed, contextualised analysis of the particular approaches of individual organisations, the purpose of this paper is not to "name and shame" individual organisations, but rather to draw out cross-organisational patterns regarding the ways in which international agencies engage with and draw on ideas regarding gender and education contained within international frameworks in their policy and practice.

\section{International organisations engaging with global frameworks}

The relationship between international organisations - including those interviewed for this research - and the Dakar and MDG frameworks discussed above is a close one. King (2007) has pointed to the key role played by multi-lateral agencies in constructing the global agenda on education, cumulating in the Dakar conference and the Millennium Summit. Meanwhile the formation of the Global Campaign for Education (GCE) - which brought together Northern and Southern Civil 
Society organisations, NGO and teacher unions campaigning on education - in 1999, provided a focus for coordinated civil society action around Dakar in 2000 (Gaventa \& Mayo, 2009; Mundy \& Murphy, 2001). The Dakar process itself, and the presence of the coordinated civil society coalition in the form of the GCE enabled civil society actors to be established as significant actors in the push towards achieving Education For All (Sivasubramaniam, 2008). Since 2000 global organisations have played an important role in influencing the processes of implementation of the Dakar and MDG frameworks through participation in policy dialogue at national levels (Little, 2008), reviewing progress on EFA and MDGs, generating indicators for cross-country monitoring, discussing, mobilising and disbursing finance, campaigning and advocacy, and the establishment of partnerships such as the UN Girls Education Initiative (UNGEI) and the Education for All Fast Track Initiative (FTI) to galvanise action and mobilise resources (UNGEI, 2006; Gaventa \& Mayo, 2009).

The interviews conducted for this research confirm this continued process of engagement with global policy frameworks among international agencies and civil society organisations working on education. They suggest that moreover that actors in international organisations are actively drawing on these global framework in developing their own policy and programmes. It was clear that the global frameworks, and the ideas around gender equality contained within them played an important part in the different dialogues and negotiations around gender that take place within, between and beyond organisations. When asked about international policy frameworks, and how they were important for their organisations, most spoke participants primarily about the MDG framework and viewed it as the key framework within which they situate their work. However a smaller number identified more closely with the Dakar EFA goals. Only three participants spoke explicitly about the Beijing Platform for Action, and only one -from an international NGO - saw it as central to their organisation's work and thinking. On the whole, participants from UN or bi-lateral agencies spoke more to the MDGs, while civil society participants often associated themselves more closely with the EFA goals, possibly reflecting the importance of the Dakar conference in mobilising civil society and in the establishment of the GCE. However, the division between civil society and UN / bi-lateral agencies was not clear cut. Some participants from international NGOs, particularly those who saw their work as being closely linked to that of UN agencies, or who were active in the UNGEI partnership, saw the MDG framework as central for their work.

Despite differences in terms of which frameworks participants identified with most closely as individuals and as institutions, all recognised the MDG framework as playing a dominant role in terms of shaping international policy and action around gender and education, with implications for their own organisations' policy and practice. However the ways in which the participants spoke about the MDG target for gender parity in education varied. A close analysis participants' responses revealed the existence of two different views regarding the implications of the MDG target for addressing gender in education work. In the first view, the MDG framework, and MDG 3 in particular, were seen important for leveraging action around gender and education within participants' own institutions and in global policy spaces more broadly. In the second, more critical view, the MDG framework, and the way in which gender is conceptualised within it in terms of gender parity, was seen as limiting work on gender and education to a very narrow focus on access and enrolment, and thus undermining the broader agendas articulated in Dakar and Beijing. These two approaches to the MDGs are discussed in the following sections.

\section{The MDGs as a tool for leveraging action}

All the participants from donor and UN agencies, as well as three of the participants from International NGOs stressed the way in which, through opening up space for discussion, MDG3 constituted an important tool for leveraging action on gender issues in education. One participant from an international NGO explained:

I see that most of them are minimum standards because we are talking about basic education, it's a minimum standard. Gender parity, a minimum standard... Ok, those are starting points for discussion and I think that is good. 
Starting these discussions were seen as important for catalysing work around gender both within and beyond their organisations. Several participants spoke of the need to use the MDGs strategically to overcome organisational resistance to working on gender. One participant - who clearly felt frustration with the lack of a strong gender focus within their (Non Governmental) organization, described employing a number of strategies to advance work on gender. These included linking gender equality instrumentally to broader poverty reduction goals - a strategy that has been used by gender advocates elsewhere (Mukhopadhyay, 2007; Kabeer, 1999; Standing, 2007) - and, importantly, drawing on global frameworks including the MDGs. They explained:

For me, for the type of work that I do, they are useful because... [it] forms a framework that can push us. It can help us engage with government, because governments have agendas they wish to meet... It can help us engage with partners on a more local level, we have a mandate. So I think, in terms of our relationship, in terms of advocacy whether internal or external, they are very useful

This participant explained how they drew upon the work and reports of other organisations to push gender within their own work, emphasising the often competitive nature of the relationship between agencies. In fact the relationships that exists between different global organisations active in the Education for All movement, and involved in this research take on multiple - and sometimes contradictory - forms, involving competition as well as collaboration, funding and processes of advocacy and influencing. Often these different types of relationship may occur all at once, as expressed clearly by a participant from an international NGO when discussing their organisation's relationship with a UN agency:

we've got this... four dimensions to our relationship with [them]: they're our partner, because they are in many ways; they're our donor - because they obviously sub-grant to us; they're our advocacy target - because we're trying to influence them; and they're our competitor, because we tap into the same groups of people for fundraising.

In negotiating these relationships, most participants' responses suggested that the MDG framework played out in important ways, and in doing so acted to encourage convergence in the ways in which participating organisations approach issues relating to gender. In some cases this occurred through the opening up of space for dialogue. For example, one participant, from another international NGO, referring to the UNGEI (UN Girls' Education Initiative) coalition explained:

I think for us the Millennium Development Goals, while there are questions around how achievable, how committed people are to them, I think it does provide that framework of accountability in the context of girls education and the urgency for this generation. Its for us I think the most useful and tangible framework to be able to do that. And... particularly in the context of UNGEI, to be able to have some kind of frame of reference to be able to have a dialogue... others around these kind of issues. We're all signed up and we're all in the same space. I think it does put us in the same space in a way that some of the other frameworks haven't necessarily done.

MDG 3 was seen as providing an advocacy tool, used for pushing action on gender by other agencies and within the international community as a whole. The same participant explained:

I think for us particularly the MDG framework has been a very valuable framework there to be able to call others to account but also to really emphasise the urgency of the situation, particularly in relation to girls 
The MDGs were also viewed as important by some in their interactions with national governments - ensuring that gender was part of the conversations they were able to have about national education plans and monitoring. One participant from a donor agency for example, explained:

because gender is there (in the MDGs) and quite strong - that's where it really comes into the MDGs, in education - it has necessitated it being monitored at country level, in very quantitative ways, but it is there. And I think without that it might drop off.

These comments suggest that the MDG framework, and MDG 3 in particular, were seen by most participants as playing an important role in ensuring attention to gender issues both within their own organisations, and in their relations with others, particularly where concern with gender might otherwise have been absent. The MDG target on gender parity was used to ensure that both the programme and policy work of individual organisations included some concern with gender. This was evidenced by, for example, policy statements focusing on the need for action around gender disparity and access to education for girls, or the disaggregation of the numbers of children out of school by gender and the development of specific programmatic interventions targeted at girls.

These responses, which point to the way in which the MDG has been used by participantsto ensure that gender is considered in education programme, policy and campaigning work, suggest that, to some extent this process has contributed to enabling a very 'thin' and technically inflected form of gender mainstreaming to take place within and between their organisations. In this thin version of MDG-driven mainstreaming, gender is seen largely as a technical issue. Thus work on gender was often associated by participants with technical expertise in the form of "gender experts", accompanied by a focus on "what works" to get girls into school. One NGO participant, for example, when talking about the difficulties of ensuring that new programmes reach as many girls as boys, explained how their approach needs to be evidence-based and draw on experience of what "they think they can practically do":

\section{So some real evidence based analysis of what to do would be helpful... And I think some answers would be helpful, whether that means a tool kit or whatever.}

This version of gender mainstreaming, while ensuring some concern with gender within education work, is not, however, unproblematic. Tying legitimacy to talk about - and work on gender issues to the MDG framework - and the MDG3 target in particular - raises questions about the sustainability of a commitment to gender equality that is externally rather than internally driven. This was highlighted by the comment of one participant who recognised that gender slipped off their campaigning agenda once the 2005 MDG target to get equal numbers of girls and boys into school had passed. Moreover, despite recognition among participants of the need to consider issues of quality, equality and empowerment, a much narrower focus on numbers associated with the MDG parity target appears to dominate. As a consequence, more substantive issues of gender equality that go beyond the parity framing of the MDG often went un-discussed and un-addressed.

\section{Moving beyond parity}

The limits of a gender agenda tied primarily to the gender parity target, was a concern raised by all participants with the exception of one NGO participant, who saw the parity target and "a desirable goal". Even participants who had stressed the value of the MDG target in enabling them to push a concern with gender, recognised that limiting this concern to gender parity was not without problems. A participant from a donor agency, for example, commented:

What I do think has been unfortunately for me mostly has been the focus on access... I think that has been just, has skewed the way we look at education... and the whole box of teaching and learning and what actually happens in school has somehow got lost in this ten years of push for access. 
Another participant, from a UN agency explained:

what is bad is that its defining gender in an incredibly narrow way as just about enrolment. It's even defining education in an incredibly narrow way.

For some participants, this limitation, did not entirely invalidate the MDGs themselves, or the use of the MDG 3 target to galvanise action around gender and education. Instead they pointed to the need to use the MDGs strategically and to recognising that gender parity should be seen as a starting point rather than the end goal. One participant, from a donor agency suggested that to do this, it was necessary to separate the political use of the MDG to draw attention to the links between gender and education at an international level, from the process of implementing programs:

\section{We should have perhaps taken more of a clear separation between the political messages and then the actual implementation on the ground}

However, one participant, from an international NGO questioned the extent to which it is possible use the MDG target combine a narrow focus on gender parity with a more transformative agenda, suggesting that in some cases the focus on gender parity within the MDG framework resulted in work on gender being constrained, rather than advanced. They argued that the narrow framing means that, far from being helpful, the MDGs actually "actively undermine" the more substantive Education For All and Beijing Frameworks, which encompass a broader - and more transformative agenda regarding gender and education and education:

The MDGs narrowly focuses on this sort of parity question which is quite limiting and leads to quite sort of instrumentalist interventions rather than things that are committed to a transformation

This participant was concerned about the way in which the predominance of the MDGs on the global stage has captured "language and territory" of the wider concerns around gender and education, linked to ideas around equality and empowerment, contained within the Dakar EFA and the Beijing platforms. While they did not see this as a concern within their own organisation - which had explicitly adopted a focus on women's rights and empowerment, drawing on the Dakar and Beijing frameworks - they felt that, within the global education community as a whole, and among donors in particular, this has meant that not only have wider concerns with gender equality within schools been ignored, but so too have other issues such as adult literacy. They argued that the power dynamic between national governments and donors means that national governments restrict themselves to including things they know will get funded in their national education plans. As a result, these have been limited to efforts to get girls and boys into primary and secondary school at the cost of spending in other areas important for gender equality but not directly tied to the MDG target of gender parity.

This view suggests that the MDGs, representing a powerful global agenda, have been used to justify or legitimise particular kinds of work around gender, while excluding others. The suggestion is that as a focus on gender as parity is pushed by the global policy community - the ability of national governments or civil society groups to contest such an interpretation, or advance work linked to other understandings of gender constrained.

The power that the MDG stress on gender parity holds in international policy discussion and enactment was also emphasised by other participants. One civil society participant explained how civil society has sometimes found itself co-opted by the "MDG parity agenda". Referring in particular to the perceived need to "claim success" regarding progress on gender parity at the cost of deeper discussion of broader issues relating to gender equality in schooling :

I think the other thing, the progress on gender parity in enrolments, you know there is a way in which global civil society, however hard they try not to, does sort of absorb the narrative of the powerful and maybe we've done that a bit too much 
Comments such as these are important in that they point to processes of power and exclusion that contribute to reinforcing a narrow interpretation of gender, which limits attention to the concerns with equality and empowerment articulated by the Dakar and Beijing frameworks, and in the framing of the broader MDG goal. In this case the comment suggests a process of exclusion occurring both between different sorts of global organisations, and between global agencies and national governments. However, a close examination of the interviews suggests that such processes of exclusion do not only take place between these organisational spaces, but also within them.

\section{Embedding gender?}

The interviews suggested that for most organisations, establishing gender as an institutional priority is a fairly top-down process. This has not always ensured that local understandings of gender relations are able to "bubble up" to the global. One participant from an international NGO recognised that gender issues that might be important in particular local contexts - Female Genital Mutilation (FGM) for example, got lost in overall institutional programme and policy activities. Another, from a different NGO, recognised that very different understandings of what gender equality in education means existed within their organisation and among their partners - and that it was not easy to bring these into dialogue with each other:

Underneath the discourse around girls' education, what we are trying to transform, there are some people who are keen to have girls go to school and stay in school so that they become better housewives

Significantly they acknowledged that a view that work on gender was and should be an important part of their organisational work on education was not universally shared by all:

there are people ... who say "oh well your model of gender is a western imported model or a Northern model and we have to be, well, first of all to challenge that because I don't think it is, it's just a defensive tactic that people use to block change...

Such explicit recognition of the difficulties of working on gender within an organisation working in very different cultural contexts was not forthcoming in all the interviews. However it raises important issues around ownership and the sustainability of work around gender, and how to engage "resistant" voices, and dialogue across different cultural understandings of gender. When discussing approaches to gender within their own organisations, all participants saw leadership from the top of the organisation as playing a critical role. Resistance to working on gender at the level of headquarters was identified as an important factor in hindering progress in some organisations. As discussed above, in tackling such resistance some participants drew on the MDGs and the existence of the gender parity target, to push gender as an issue and leverage action. However, tackling resistance "from below" and engaging local interpretations of gender equality may require a rather different approach. This entails moving away from a view of mainstreaming gender as a technical exercise - as entailed by the use of the gender parity target to leverage action around gender, and drawing on the feminist analyses of gender mainstreaming as a political process in which paying attention to issues of attention to issues of voice and participation, and the mobilisation and articulation of demand, as well as the contested nature of different meanings of gender and equality (Mukhopadhyay, 2007; Woodford-Berger, 2007). 
Indeed, the data collected for this research suggests that opening spaces for dialogue and critique that enable local as well as global meanings and understandings of gender to be articulated, debated and contested is essential if gender is to be embedded in institutional practice in a meaningful way. However it also points to the difficulties of doing this, when concerns with gender are associated with a global agenda, particularly one in which meanings of gender are narrowly defined.

Overcoming this requires taking deliberate steps to ensure that different voices - including women's voices - can be brought into organisational discussions around gender.

\section{Connecting with women}

Wendoh and Wallace's (2005) work on gender mainstreaming in Africa suggests that strengthening the capacity of women to articulate the sorts of changes that they want to see can be critical in enabling change to occur. Similarly Rao and Kelleher (2003) have argued that efforts to mainstream gender within organisations have been limited by their failure to connect initiatives to support women on the ground and Kabeer (2008) has emphasised the importance of building links with grassroots women's organisations. The need to engage women's voices both within and beyond their organisations, as part of the process of embedding gender was recognised by several participants. One participant from an international NGO spoke about the importance of having a well supported and empowered women's rights team, within the organisation, with whom they had established close links in support of work around gender and education. They also however pointed to the importance of building links with feminist groups at local levels:

you have to make sure you are linked to the women's movement and the feminist movement in each country, because it's not as if there aren't people in each and every country who are deeply committee to change and very critical of the sort of patriarchy which they suffer from on a day to day basis and they have their own detailed analysis which is distinct in each country but which has got certain common fundamental principles of women's rights and wider human rights

However, it appears that building these links is not always easy. The interviews reveal that the distance that exists between those involved in the Education For All movement and the women's movement is a pervasive form of disconnection between work on gender and on education. While some participants talked about limited links with particular women's organisations in their work at local or national levels, these tended to be those whose work was specifically focused on education, with a particular focus on girls, rather than with women's organisations more broadly. Only one participant appeared to have developed deliberate links with national level women's movements with a wider remit around issues including, for example, gender based violence.

These disconnections between those active in the education for all movement and women's organisations were equally apparent at the global level. Two participants from international NGOs explained:

since [Dakar] the feminist organisations have one their way and the educationalists have gone their way. And I think that as long as we don't unite in our efforts to do this it's still not going to work."

There should be a connection but there isn't.

The lack of connection between the two movements can be linked to a number of different issues: participants, for example, cited the different histories of each, and the difficulties of working across sectors more broadly. The MDG, in with its explicit linking of education and gender within MDG 3, could have provided a meeting point, bringing actors concerned with education and women's organisations closer together. However it would appear that this has not happened.. This may, in part be linked to the ambivalent relationship that many women's and feminist organisations 
have with the MDGs. In contrast to the large-scale mobilisations in support of the Beijing Platform, many feminist activists have been reluctant to engage with the MDG framework, whose potential to advance a transformative agenda for women's rights and gender equality has been questioned (see for example Kabeer, 2005). In particular, feminist groups have criticized the failure of the MDG to look beyond parity in education and consider issues of particular concern to the women's movements including reproductive rights, violence against women, women's unpaid labour or women's literacy (Barton 2005). The MDGs have thus been dismissed as 'Most distracting gimmicks' (Antrobus 2005).

One participant, from a donor agency, recognised this as a problem, suggesting that the way in which gender parity in education had been established as the key target for MDG 3has not encouraged increased engagement between women's organisations and the education movement:

\section{"I think there is a bit of a feeling since the MDGs came, and this has been said to me, that education has got up there and we need to, it's almost like it's not fair"}

Building connections between education and women's organizations at local and global levels is important, to deepen discussion around issues of equality and what addressing gender in and through education work does and could mean, and to help build ownership of the processes through which particular forms of gender get mainstreamed or embedded into education work. However, doing this is requires moving beyond an approach to gender framed around the MDG parity target. Re-engaging with the Beijing Platform for Action, and the links established between gender and education within it, and building partnerships with groups that mobilized around Beijing could be an essential step in doing this.

\section{Conclusion}

Unterhalter has advocated for "a strategic defence of the MDG as an opportunity to think more widely about what the contents of rights in education are and how gender equality might be advanced". (Unterhalter 2007; 111) The interviews suggest that the MDGs do play an important role in shaping conversations and negotiations around gender equality in education within and between the global organisations within which participants were based. Particularly in organisations where existing work and leadership on gender issues was weak, they have contributed to opening spaces for dialogue around gender, and providing leverage - and a form of externally driven legitimacy - to developing a focus on gender in education work. In this way they have contributed to a form of gender mainstreaming, in which certain approaches to gender are incorporated into policy and programmes within and across organisational spaces. But, such a process, associated with the gender parity target within MDG 3, appears fragile, unsustained, and limited in scope.

The MDGs represent a powerful global agenda - and as such they have the power to influence and shape discussion and action around gender equality in education. The narrow interpretation of MDG 3 in terms of its specific target around gender equality has tended to constrain and contain the scope of such discussion, excluding particular voices - including the global women's movement - and limiting scope for transformation. In order to use the MDG framework to advance more substantive processes of thinking through gender equality in education there is therefore a need to look beyond the gender parity target and recapture the much broader and more ambitious scope of the MDG 3 goal - gender equality and the empowerment of women, and re-engage with the agenda for women's empowerment established in Beijing.

Moving beyond the thin - parity based - version of gender mainstreaming to a more meaningful embedding of gender in educational work, based on shared understandings of a more substantative notion of gender equality - also requires recognising that institutionalising gender is a complex political process. Paying attention to processes of resistance and critique, local interpretations of gender, and the processes of inclusion and exclusion, which determine whose voice is included or excluded, within processes of dialogue and negotiation is thus essential. To some extent the interviews suggest a need to move beyond a framework-driven focus on gender and open spaces of dialogue within and between organisational spaces. Empowering women - and women's rights and 
gender teams - within organisations can be an essential part of this. So too is engaging with locally situated gender analyses and building links out to women's groups at local as well as national and international levels.

\section{References}

Aikman, S., \& Unterhalter, E. (2005). Beyond access : transforming policy and practice for gender equality in education. Oxford: Oxfam GB.

Antrobus, P. (2004). The global women's movement. Origins, issues and strategies. London: Zed Books.

Barton, C. (2005). Where to for women's movements and the MDGs? Gender and Development, 13(1), 25-35.

Eyben and Napier-Moore (2008) Conceptualising Women's Empowerment in International Development Agencies Pathways of Women's Empowerment RPC Global Hub Working Paper. Retrieved 29/03/10 from http://www.pathwaysofempowerment.org/Pathways Working Paper1.pdf

Fennell, S., \& Arnot, M. (Eds.). (2008). Gender Education and Equality in a Global Context: Conceptual frameworks and policy perspectives. London: Routledge.

Gaventa, J., \& Mayo, M. (2009). Spanning Citizenship Spaces Through Transnational Coalitions: The Case of the Global Campaign for Education. IDS Working Papers, 2009(327), 01-43.

Kabeer, N. (1999). Resources, Agency, Achievements: Reflections on the Measurement of Women's Empowerment. Development and Change, 30(3), 435-464.

Kabeer, N. (2005). Gender Equality and Women's Empowerment: A critical analysis of the third Millennium Development Goal In C. Sweetman (Ed.), Gender and the Millennium Development Goals Oxford: Oxfam GB.

Kabeer, N. (2008). Gender, labour, markets and poverty: An overview. Poverty in Focus, 13, 3-5.

King, K. (2007). Multilateral agencies in the construction of the global agenda on education. Comparative Education, 43(3), 391-399.

Little, A. W. (2008). EFA Politics, Policies and Progress. Create Pathways to Access Research Monograph No 13. Falmer: CREATE.

Moser, C., \& Moser, A. (2005). Gender mainstreaming since Beijing: a review of success and limitations in international institutions. Gender and Development, 13(2), 11-22.

Mukhopadhyay, M. (2007). Mainstreaming gender or 'streaming' gender away: feminists marooned in the development business. In A. Cornwall, E. Harrison \& A. Whitehead (Eds.), Feminisms in development: Contradictions, contestations and challenges (pp. 135-149). London: Zed Books.

Mundy, K., \& Murphy, L. (2001). Transnational Advocacy, Global Civil Society? Emerging Evidence from the Field of Education. Comparative Education Review, 45(1), 85-126.

North, A. (2006). 'What does the Global Monitoring Report say about gender?' Equals 16 (8).

Rai, S. (Ed.). (2003). Mainstreaming gender, democratizing the state? Manchester: Manchester University Press.

Rao, A., \& Kelleher, D. (2003). Institutions, organisations and gender equality in an era of globalisation. Gender and Development, 11(1), 142-149.

Rao, A., \& Kelleher, D. (2005). Is there life after gender mainstreaming? Gender and Development, 13(2), 57-69.

Sivasubramaniam, M. (2008). Social capital, civil society and education for all: A gendered lens. In S. Fennell \& M. Arnot (Eds.), Gender education and equality in a global context: conceptual frameworks and policy perspectives. London and New York: Routledge.

Skelton, C., Francis, B., \& Smulyan, L. (Eds.). (2007). International Handbook of Gender and Education. London: Sage.

Standing, H. (2007). Gender, myth and fable: the perils of mainstreaming in sector bureaucracies. In A. Cornwall, E. Harrison \& A. Whitehead (Eds.), Feminisms in development: Contradictions, contestations and challenges (pp. 101-111). London: Zed Books.

Subrahmanian, R. (2007). Making sense of gender in shifting institutional contexts: some reflections on gender mainstreaming. In A. Cornwall, E. Harrison \& A. Whitehead (Eds.), Feminisms in 
development: Contradictions, contestations and challenges (pp. 113-121). London: Zed Books.

Tinker, I (2004) Introduction: Ideas into Action. In A Fraser and I. Tinker Developing Power: How women transformed international development. New York: Feminist Press

True, J. (2003) Mainstreaming Gender in Global Public Policy International Feminist Journal of Politics, 5(3) 368-396

UNESCO. (2005). Global Monitoring Report 2006: Literacy for Livelihood. Paris: UNESCO.

UNESCO. (2006) Global Monitoring Report: 2007 Strong Foundations: Early childhood care and education Paris: UNESCO.

UNESCO. (2007) Global Monitoring Report 2008: Education for All by 2015: Will we make it? Paris: UNESCO.

UNESCO. (2008). Global Monitoring Report 2009: Overcoming inequality: Why governance matters. Paris: UNESCO/Oxford University Press.

UNGEI. (2006). United Nations Girls' Education Initiative (UNGEI) Factsheet. Retrieved 13/05/08, from http://www.ungei.org/resources/files/Ungeifactsheet Nov06.pdf

Unterhalter, E. (2005). 'Global inequality, capabilities, social justice and the Millennium Development Goal for gender equality in education'. International Journal of Education and Development, 25, 111-122.

Unterhalter, E. (2007). Gender, schooling and global social justice. London: Routledge.

Unterhalter, E. (2008) Global values and gender equality in education: Needs, rights and capabilities In S. Fennell \& M. Arnot (Eds.), Gender education and equality in a global context: conceptual frameworks and policy perspectives. London and New York: Routledge.

Unterhalter, E., \& North, A. (2009). Global aspirations for gender equality in education: What kind of pedagogy? In Y. Raley \& G. Preyer (Eds.), Philosophy of Education in the age of Globalization New York: Routledge.

Walby, S. (2005). Introduction: Comparative gender mainstreaming in a global era. International Feminist Journal of Politics, 7, 453-470.

Wendoh, S., \& Wallace, T. (2005). Re-thinking gender mainstreaming in African NGOs and communities. Gender and Development, 13(2), 70-79.

Woodford-Berger, P. (2007). Gender mainstreaming: what is it (about) and should we continue doing it? In A. Cornwall, E. Harrison \& A. Whitehead (Eds.), Feminisms in development: Contradictions, contestations and challenges (pp. 123-134). London: Zed Books.

World Bank. (2001). World development report 2000/2001: Attacking Poverty. New York: Oxford University Press.

\footnotetext{
'This three year project, funded by the ESRC through the ESRC and Department for International Development (DFID) joint funding scheme, and directed by Elaine Unterhalter, is examining initiatives which engage with global aspirations to advance gender equality in and through schooling in contexts of poverty. The project is concerned with how these are understood, interpreted and acted upon in different sites and what meanings of gender, education, poverty and global obligation are negotiated. Case study research is examining how global policy goals are being interpreted and acted upon in 5 different sites in Kenya and South Africa and in global institutions. I am grateful to members of the project team - in particular Jenni Karlsson and Elaine Unterhalter - for helpful comments on drafts of this paper.
} 